\title{
Multicultural Education as a Dimension of Interethnic Dialogue
}

\author{
S. Fedyunina \\ Saratov State Technical University \\ Russia \\ \& \\ A. Slepukhin \\ Saratov State Technical University \\ Russia
}

Quotation information

FEDYUNINA, S; SLEPUKHIN, A (2008), "Multicultural Education as a Dimension of Interethnic Dialogue". Proceedings of the 4th International Barcelona Conference on

Higher Education, Vol. 6. Higher education for intercultural dialogue and multiculturalism. Barcelona: GUNI. Available at http://www.guni-rmies.net.

The urgency of sociological analysis of multiculturalism in Russian society is caused by strengthening of the role of intercultural interactions in the processes of global integration. In the context of intensive transnational movings and interethnic contacts, migratory processes, changes of ideological and political vectors of the development intercultural interactions get new specificity.

Today the sphere of culture and education is the most productive field for interethnic interaction, development of dialogue and mutual understanding, acting as a powerful factor of development of national consciousness, self-affirmation of ethnic generality. The role of higher education in the development and strengthening of this system of values is strategic. An interest of foreign students to getting higher education in Russian higher schools is growing, the international cooperation of businessmen, scientists, art workers, public organizations is extending.

It is well known that assimilation model of "a melting boiler" in formation of American nation (the end of XIX - beginning of the XX century), is described today by researchers of multiculturalism (V.Antonova/B.????????:2002; D.Alexander: 2001; F. Atkinson: 2000; S. Benhabib / ? .????????: 2003; A.Kuropjatnik / ?????????: 2000; U. Kymlika: 2001; V. Malakhov / ?.???????: 2002; D.Saks:1995; Tishkov/??????: 


\section{Vol. 6. Higher education for intercultural dialogue and multiculturalism}

GUNI - Global University Network for Innovation - www.guni-rmies.net

2004; S.Holl:2000) as the illustration of a myth about ethnically and cultural neutral liberal state. The term «multiculturalism» as a sociological term has been introduced for defining a policy of cultural pluralism into a counterbalance of cultural assimilation. As the political ideology multiculturalism acts as a compromise between the state and minority and majority groups, and, instead of replacement of liberal values, admits the priority of the rights of a person above the rights of a cultural group. Now governmental politicy of the countries which have accepted the doctrine of multiculturalism (the USA, the Great Britain, France, Canada, Australia, New Zealand, etc.) is associated with the official recognition of parallel existence of various ethnic groups inside one state and creation of favorable economic and legal conditions for this purpose by the state. Tolerance and respect of the rights of others are declared as a part of a modern political atmosphere, and pluralism in social and political life is regarded as a necessary part of a liberal society. Multiculturalism is aimed not only at tolerance; it is a strong desire of political circles to prevent conflicts and opposition inside the state.

Nowadays, there is no recognized theoretical model of multiculturalism. It is possible to allocate, at least, two directions: an idealized picture of "multicultural model" of the future, based on a classical liberalism, and a multicultural integration model based on a modern liberalism. The latter determines the life of ethnic minorities in accepting society with the observance of equal rights and accesses to resources, but with the absolute recognition by minorities the laws of the accepting side (Kymlica W, 2001). On the other pole - disappointment in the idea of multiculturalism, its recognition as absurd and not considering incompatibility of life styles and traditions of different cultures (F. Atkinson: 2000; D.Saks:1995). We believe, that an important point which should be considered in multicultural research is the distinction of basic forms of its display: in the states forming the population due to migrants (Canada, the USA, Australia), and in the European national states accepting migrants. The growth of ethno-cultural and ethnic political movements is stimulated in European countries by globalization and European integration.

The research of multiculturalism as a phenomenon is considered to be a multilateral and complex process which needs to be investigated both at a macro-level, and at a level of realities of a modern daily life. In a broad meaning of the term we 


\section{Vol. 6. Higher education for intercultural dialogue and multiculturalism}

GUNI - Global University Network for Innovation - www.guni-rmies.net

define "multiculturalism" as a system of social, cultural and legal values, principles of non-discrimination and tolerant interaction of groups and individuals, formations of a spiritual life of a society. It means that the life of any society can be examined in the context of presence or absence of valuable characteristics of multicultural integration. We think they are: understanding of the term "nation" in terms of citizenship; absence of overwhelming culture; presence of economic and social conditions of minority groups support ; necessary legislative base; equal educational services, common informative and communicative space; opportunity of a person cultural selfdetermination of in the choice of a style of life; presence of programs of intercultural interaction and overcoming an inequality; State power support of educational and cultural programs on saving cultures and languages of small ethnic groups. We mean by basic principles of multicultural integration: gradualness, creation of economic and social conditions of support; transformation of institutes of accepting culture; effectiveness of acts against racism, xenophobes and terrorism; creating conditions to equal access to educational services and maintenance of non-discrimination practices; formation of effective communicative space; ensuring of freedom to choose a style of life, a language of training and dialogue, a belonging to faith with unconditional observance of the legislation of the state of residing.

We think, that the Constitution of the Russian Federation, the Russian legislation and the ratified international acts, Federative State system itself, creation of the Assembly of the Peoples of Russia represent not only a sufficient legal basis for preventing illegal extremist activity and crimes because of national, racial, social and religious enmity and hatred, but preconditions for multicultural model. But on the Postsoviet space the idea of multinationality perceiving the nations in their ethnic sense is of greater degree of legitimacy whereas multiculturalism is sometimes denied as the threat to the developed social order. The contents of stereotypes and the character of relations between people depend on the ability of the population to adapt for difficulties. If such adaptation occurs mainly in negative forms the major stabilizer of group behavior becomes the searching of the "enemy", and the struggle with him compensates the feeling of fear and vulnerability. And if the institutional or governmental control or an infrastructure of social support is strong, these moods are 


\section{Vol. 6. Higher education for intercultural dialogue and multiculturalism}

GUNI - Global University Network for Innovation - www.guni-rmies.net

muffled and can be not mobilized. The resources of interethnic and intercultural integration should carry not only the organization of "economic niches", but, first of all, perfection of legal base and practices in combination with introducing multicultural principles in the activity of the state structures directly cooperating with the population. Multiculturalism as the policy and practice should be formed at different levels: in individual experience, in a daily life, in culture, mass-media, in institutions and organizations, in the sphere of legislation and national policy.

In the Russian Federation of the Post-soviet period regional programs of national cultures development have been functioning in many areas since 2000. In the Volga Region (Saratov, Samara, Volgograd areas) such programs are known to start earlier. Having leaded the analysis of realization of the target program "Nationalcultural development of people of the Saratov area" 2003-06, we came to the conclusion that it had on the whole positive results but exactly in the questions of multicultural integration was not effective enough. Among positive results we can mention appearance of many schools with studying national languages, participation of ethnic groups in different ethnic programs. So traditionally the project was focusing on saving and enrichment of national folklore, language and customs. But the problems of propagation of the ideas of tolerance and interethnic cooperation, increase of efficiency of cultural and social integration of immigrants and representatives of national minorities were insufficiently covered. In some areas the acts of migrant phobias were marked. Similar lacks characterized the program "Revival" of ethnic Germans in the Volga region, accepted at the end of the ninetieth. In the new program «Nationalcultural development of people of the Saratov area» for 2008-10 the attention is noticeably strengthening on a social sphere, harmonization of interethnic relations, education of tolerant consciousness, and a role of national public associations as institutes of a civil society in realization of national policy.

In 1990-2008 in the Russian Federation federal and regional projects and programs of tolerance have been developing. These programs have contributed to the development of ethno-cultural consciousness, revival of ethnic identity of many groups. Among them are: "Russia multinational. Peace through culture"; "Formation of tolerant consciousness and preventing maintenance of extremism in the Russian society"; 


\section{Vol. 6. Higher education for intercultural dialogue and multiculturalism}

GUNI - Global University Network for Innovation - www.guni-rmies.net

"Formation of tolerant social samples and norms in the Internet-communications", initiated by Federation of the Internet-education; a Program of increasing tolerance in the dialogue for children (Composer-developer G.V.Serikov, St.-Petersburg). We can also mention the TEMPUS project "Improvement of Interethnic attitudes and development of tolerance in Russia" (V.Tishkov, S. Sokolovsky, 2002). In 2006 the target program of tolerance development was accepted in St.-Petersburg. It is supervised by the governor V. Matvienko. "Lessons of piece" are spent by students members of «The African unity» in St.-Petersburg. A program of tolerance called «The Capital of Multinational Russia» is successfully working at many schools In Moscow. All these and many other programs and projects, have brought and are bringing the contribution to the development of tolerance though there are problem moments in their realization.

In 2006 with the help of focus-groups method S. Fedyunina examined opinions of students belonging to ethnic minority in two large Saratov universities on situations of training in Russian higher schools (???????? ?.?.: 2006). In two focus-groups there were representatives of different nationalities of Russian Federation (Tatars, Chechens, Ossets) and foreign students (from Kazakhstan, Azerbaijan) - 17 persons, including 11 students and 6 young teachers (from them - 9 women and 8 men). First of all it was interesting to know the opinions of the students trained at the Faculty of Law as in the future this category of students would fill up the numbers of employees of lawenforcement structures and legal professions i.e. would be directly involved in the processes connected with protection of human rights.

Students of the Faculty of Law have noted insufficient attention to the problems and principles of multiculturalism and tolerance at the Faculty of Law, in their educational programs, whereas students trained on the language program have emphasized the importance and urgency of modules on intercultural dialogue available in the curriculum. All respondents were unanimous in the question, whether it is necessary to include such themes as interethnic relations, intercultural distinctions, problems of discrimination and infringement of the rights on the basis of ethnics or race in foreign language curriculums. Recognizing evidence and complexity of the problem of ethnic discrimination, the students identify it on institutional level, denying 


\section{Vol. 6. Higher education for intercultural dialogue and multiculturalism}

GUNI - Global University Network for Innovation - www.guni-rmies.net

xenophobes within the nearest social environment; ascertain experience of ethnic discrimination in education system.

Today about one hundred thousand foreign students more than from 150 countries of the world are educated in Russia. Russia expands the participation in the international market of educational services. The Russian system of higher education moves aside recognitions of the Russian diplomas all over the world as a member of Bologna agreement, and a certain number of foreign students educated in higher schools is one of the parameters in the ratings of higher educational institutions. The Russian system of higher education as a whole is perceived by foreign students positively, it gives a worthy level of professional knowledge students allowing them to find highly paid jobs after graduation. At the same time there are numbers of problems in Russian higher schools. It concerns the conditions of life and training, personal safety of foreign students, efficiency of language training.

In A.Slepukhin' research (???????? ?.? :2004, 391-392) it is revealed, that a number of factors such as interactions with other students, Russian teachers, representatives of administration, cultural features of the place of study and residing influence the process of adaptation in other culture. Negative adaptation in this social environment arise aspiration to return home. The process of adaptation of foreign students to conditions of Russian higher school is determined in many respects by initial motivation of students, their readiness to accept other rules of life and cultural norms. In the long term the improvement of the quality of residing, organization of leisure, perfection of health services and the system of protection of the rights of students can have positive influence on the image of provincial higher schools. Consolidated activity of Russian higher schools aimed at the recognition of the Russian diplomas in other countries will have doubtless effect as well. This activity should be connected with the principles of multiculturalism, realized in a daily life and culture of any educational institution, and also in educational programs.

We think that Institutes of culture and education, civil society have special authority «to make opinion», to form new understanding of social problems in a society, to promote a wide circulation of values of tolerance and multiculturalism. Development of the principles of intercultural dialogue, training of practical skills of the intercultural 


\section{Proceedings of the $4^{\text {th }}$ International Barcelona Conference on Higher Education}

\section{Vol. 6. Higher education for intercultural dialogue and multiculturalism}

GUNI - Global University Network for Innovation - www.guni-rmies.net

communications become today the global tendency at all levels of education system. This training can be introduced only in a special educational environment, which itself has innovative character and is focused on positive social changes. The effective and constructive solving of this specific problem demands recognition of intercultural tolerance development as a prior direction of educational policy of the state at federal and regional levels with a view of preventing maintenance of xenophobia and struggle against extremism.

Saratov State Technical University trains students in $\mathbf{5 6}$ specialisms. At present about 28000 students study at SSTU. Among them are students of different ethnic groups and foreign students. The programs of multicultural orientation developed at SSTU are based on the learner-centered approach to educating modern specialist who possess not only professional knowledge, but also skills of effective intercultural interaction, understanding of the importance of the variety of social identities and observance of human rights in a modern multicultural society.

We think that multicultural education should be based on theoretical principles of humanism and critical training, should act as the purpose of educational reform in the direction of creating equal opportunities for all the students. In dynamic aspect it is the change of all components of education as the institute, including organizational structure, methods of training and education, principles of management. It is the continuous process demanding long-term efforts, and also carefully planned actions and monitoring. Multicultural education opposes social inequality and discrimination; raise the questions of cultural pluralism and equal access to resources.

Key ideas on multicultural education were realized in the programs and options for students of such specialisms as «Social work», «Social anthropology», «Service and Tourism», applied qualification «the Translator in the Sphere of Professional Communications», in cross-cultural trainings of SSTU teachers participating in different international projects since 1998. They were called «Intercultural interactions», «Intercultural rhetoric». 


\section{Vol. 6. Higher education for intercultural dialogue and multiculturalism}

GUNI - Global University Network for Innovation - www.guni-rmies.net

TOPICS in the Course "Intercultural Interactions"

(102 hours: 68 academic h-s. /32 - autonomous learning)

1. Contests of intercultural interaction.

2. Stereotypes in communication environment of modern society.

3. Opposition «WE - THEY» and cultural Identity.

4. Language personality in intercultural communication.

5. Professional discussions and talks in international and multicultural communication.

6. Interaction of language and society in the contexts of globalization and multiculturalism.

7. World language situation and national language policy.

8. Cross-cultural trainings as an opportunity to form tolerant and non-conflict behavior.

Case-study in Cross-cultural Training

- The situations examined are collections of critical incidents happened with people when they interact extensively with representatives of other cultural backgrounds;

- $\quad$ Case-studies examine the nature and the development of communicative styles and practices of cultural groups, their impact on interpersonal communication within and between groups.

- Particular attention is given to practical strategies for recognizing and overcoming intercultural misunderstanding.

Conclusion. Globalization creates new conditions for the whole system of education, which includes language and international education.

National culture as a shared system of assumptions, values and beliefs of people will have a grate impact on motivations, learning and communication styles and other factors in global education process. 


\section{Proceedings of the $4^{\text {th }}$ International Barcelona Conference on Higher Education}

\section{Vol. 6. Higher education for intercultural dialogue and multiculturalism}

GUNI - Global University Network for Innovation - www.guni-rmies.net

The values of globalization and multiculturalism can be realized in the learning process where students acquire cross-cultural and rhetoric competence; create a basis for effective professional development. 


\section{Proceedings of the $4^{\text {th }}$ International Barcelona Conference on Higher Education}

\section{Vol. 6. Higher education for intercultural dialogue and multiculturalism}

GUNI - Global University Network for Innovation - www.guni-rmies.net

\section{Bibliography}

1. ???????? ?. ?. (2002). ??????????????? ?????? ?????? ? ?? ?: ??????? ???????????????????. ???????: ????.

2. ???????? ?.(2003).?????????? ????????: ????????? ? ???????????? ? ?????????? ???: ???. ?. ????. ?.: ?????.

3. ?????????? ?. (2000).??????????????????: ???????? ?????????? ??????????? ?????????????? ??????. ???

4. $\quad$ ??????? ?. (2002). ?????????????????? ? ????????????? ????????????? ???????, ??? ???. ?. ?. ???????? ? ?. ?. ???????., ?.:?????.

5. $\quad$ ???????? ?.? (2004). ?????? ??????????? ? ???????? ????????????: ????????, ????????????, ?????????. ?.: ?????

6. ?????? ?. (2004). ???????? ????????? ????????????? ????????????? ????????? ? ????????????????????? ??????????????? ? ?????????? ?????????, ?.: ?????, ?. 7-12.

7. ? ?? ???? ?.?. (2006). ??????????????? ???????? ? ????? ?????????: ????????????? ????????? ?????????????????? ? ?????????? ????????. ???????: ????

8. ALEXANDER J. (2001). "Theorizing the "Models of Incorporation": Assimilation, Hyphenation, and Multiculturalism as Varieties of Civil Participation", Sociological Theory. 19, (3). P. 37-49.

9. ATKINSON P (2000). A study of our decline/ http://www.users.bigpond.com/smartboard/mltcult.htm. 
Vol. 6. Higher education for intercultural dialogue and multiculturalism

GUNI - Global University Network for Innovation - www.guni-rmies.net

10. HALL S. (2000). "The Multi-cultural Question", Settled multiculturalisms, London: Zed Books, P. 209-241.

11. KYMLICA W. (2001). Politics in the Vernacular: Nationalism, Multiculturalism, and Citizenship, Oxford: Oxford University Press.

12. SAKS D. (1995). The Diversity Myth: "Multiculturalism" and the Politics of Intolerance at Stanford, D. Sacks, P. A. Thiel. Oakland, California: Independent Institute. 